\title{
THE EFFECT OF CIRCUIT GAMES ON THE PHYSICAL FITNESS OF STUDENTS IN RAPPOCINI STATE PRIMARY SCHOOL MAKASSAR
}

\author{
${ }^{1}$ Juhanis, ${ }^{2}$ Hasmyati, ${ }^{3}$ Benny \\ Correspondence: State University of Makasar, Makasar, Indonesia \\ E-mail: juhanis@unm.ac.id, hasmyati@unm.ac.id, benny@unm.ac.id
}

\section{Abstrak}

Penelitian ini adalah jenis penelitian deskriptif melalui pendekatan kuantitatif yang bertujuan untuk mengetahui; Pengaruh Permainan Sirkuit Terhadap Kebugaran Jasmani Pada Siswa SD Negeri Rappocini Makassar. Populasinya adalah seluruh siswa SD Negeri Rappocini Makassar. Sampel yang digunakan adalah seluruh siswa putra kelas V SD Negeri Rappocini Makassar sebanyak 30 orang. Teknik penentuan sampel adalah dengan teknik Purposive Sampling. Teknik pengumpulan data menggunakan survey dan tes pengukuran. Teknik analisis data yang digunakan adalah analisis deskriptif, analisis uji t-test melalui program SPSS 21 pada taraf signifikan $\alpha=0,05$. Hasil analisis data menunjukan bahwa: Hasil uji-t diperoleh nilai thitung sebesar sebesar 26,107 dan nilai t tabel pada $d k$ (19) sebesar 2,045 dengan tingkat signifikansi sebesar 0,000. Oleh karena nilai $t$ hitung lebih besar dari $t$ tabel $(26,107>2,045)$ berati ada pengaruh yang signifikan permainan sirkuit terhadap kebugaran jasmani pada siswa SD Negeri Rappocini Makassar.

\section{Kata Kunci: Permainan, Sirkuit, Kebugaran jasmani}

\begin{abstract}
This research was descriptive research with quantitative apprōach that aimed to find out; Effects of Games Circuit toward the Physical Fitness Students of Rappocini State Primary School in Makassar. The population was all students of Rappocini State Primary School in Makassar. The samples were all Fifth Grade Students of Rappocini State Primary School in Makassar as many as 30 people. Sampling technique was by purposive sampling technique. Using survey data collection techniques and test measurement. Data analysis technique was descriptive analysis, analysis of t-test by SPSS 21 at significant level $\alpha=0.05$. The results of data analysis showed that: the t-test results obtained by value $t$ arithmetic amounted at 26.107 and t table at dk (19) amounted to 2.045 with a significance level of 0.000. There fore the value of $t$ is greater than $t$ table (26.107> 2.045) means no significant effect on the physical fitness of the game circuit on the fifth grade students of Rappocini state primary school in Makassar.
\end{abstract}

\section{Keywords: Games, Circuit, Physical fitness}

PJKR_

http://jurnal.unimed.ac.id/2012/index.php/jpehr 


\section{Introduction}

Physical fitness is a condition where the body has the ability to do an activity well without causing significant fatigue. Physical fitness is a basis for being able to do life activities including learning activities. The higher the physical fitness of a student will usually be easier for students to receive the lessons. As addition, physical fitness is the ability to perform tasks well even in difficult situations, where people who lack physical fitness, will not be able to do it. Sudarno (1992) stated that "Physical Fitness is the ability of body in making adjustments towards the physical charge provided without causing the excessive fatigue. Sadoso (1992) stated that physical fitness is the most important component of physical conditions in carrying out work abilities or activities is (1) strength, (2) cardiovascular endurance, (3) muscular endurance \& (4) flexibility. Sudarno (1992) stated physical fitness is a functional capacity that can improve quality life, without feeling exhausted and still have the remaining reserves of energy to enjoy their free time and for sudden needs, Marsudi (1997) stated that physical fitness is essentially about the ability and physical ability of a person to carry out their daily tasks effectively and efficiently in which is relatively long without getting meaningless tiredness, and still has reserve energy to carry out other activities and can still enjoy his free time. Based on this explanation, physical fitness is an absolute thing which is had by human who wants to live healthy and fit.

Related to experts' opinion above, physical fitness is a condition where the body is able to do its task and daily activities well and efficiently without experiencing significant exhaustion and the body still has spare energy either to overcome sudden emergencies or to enjoy leisure time.

In the improvement and coaching of sports in particular starting from the most basic level, which is in accordance with the circumstances of the writer who will serve as a physics education of sport and health teacher in primary school. The implementation of physical education in sports and health is one of the facilities in the framework of developing the quality of Indonesian human resources, the expected results that can be achieved require quite a long time. Therefore, efforts to foster community members and students through physical education in sports and health require patience, sincerity and a systematic and continuous program.

As an educational effort, we hope that physical education of sports and health in formal education institutions can develop more rapidly in order to be able to become the foundation for the development of national sports. The process of forming attitudes and generating motivation is started when someone is in primary school. Understanding this, instructors, especially in primary schools must have the ability and understanding of how to, foster and enhance one's ability to carry out movement and exercise, with adequate abilities, knowledge and skills that are expected to increase the competence of teachers in teaching and 
training so that teachers can understand that each individual's abilities will not always be the same.

One of the goals in doing sport is to improve physical fitness, and this goal can be achieved if sport exercising is done correctly, which is in accordance with the principles of sport. This will have a very good and great influence on one's body, besides stimulating body growth it also increases spiritual development. Thus, the work and function of the body's organs and metabolism in the body will work efficiently and also stimulate blood circulation, breathing and the nerves system.

The problem in this study is about the still the low level of physical fitness of students at the Rappocini Primary school Makassar. Researchers saw this symptom based on observations of researchers at this school on May 10, 2016. Researchers saw there were still many students, who were less eager to participate in sports activities / physical activities. In doing sports movements, it seemed that most students were less serious. Based on this fact, sports activities needed to be pursued through the form of games in order to improve students' physical fitness.

Physical conditioning exercises play a very important role in maintaining or increasing the degree of physical fitness. The degree of physical fitness of a person is crucial for his physical abilities in carrying out his daily tasks. The higher the degree of physical fitness of a person is, the higher of someone's physical work is. In other words, his work will be more productive if his physical fitness is increasing.

Besides being useful for improving physical fitness, physical condition training is a fundamental program in fostering athletes to excel in a sport. Athletes who have a good level of physical fitness will avoid the possibility of injury that usually often occurs if someone does heavy physical work, Muhajir (2004).

The form of circuit games is: Basic movements in the form of games carried out in a row from the first movement to the last through several posts, Santoso (2007). Circuit game material done between one post with another one is not the same but the time required at each post is the same, so the exercise can be completed at the same time.

Circuit game is a way of training in which the groups are grouped and each group performs a method of training, at the specified time the groups change places. Meanwhile, according to Harsono (1988) circuit trainning is a physical condition training system that can simultaneously improve the overall fitness of the body, namely components of power, endurance, speed, flexibility, mobility and other physical components.

\section{Method}

This type of research was experimental research that revealed the effect of circuit games on physical fitness for fifth grade students of Rappocini State Primary school Makassar in 2015/2016 Academic Year. This research was conducted in the Rappocini field Primary school in Makassar. The duration of the research was conducted in September 2016. Collecting of research data was adjusted to the Physical Education schedule. 
The research variable is the object of research or what the focus of research is, Suharsimi A (2002). The variables in this study consisted of two types of variables namely the independent variable (predictor) and the dependent variable. The independent variable in this study is: Circuit game and the dependent variable in this study is: physical fitness. The population in this study was all fifth grade students of Rappocini State Primary school Makassar. The number of samples used in this study amounted to 30 people using the Purposive sampling technique.

The method used in this study was an experimental method by using a quantitative treatment approach, circuit training is then measured physical fitness using TKJI. In planning an exercise program that was given by researchers to the research subjects as many as 16 meetings, conducted 3 times per week for 5 weeks so that the total of exercise was 16 meetings. For TKJI each participant had to carry out each series of tests in sequence, had not to be intermittent and may not be more than one. If they did not carry out one test or more and it could be deemed as a failure. Officers for TKJI there were 10 people in each test item there were 2-3 officers to record the results of tests conducted by each participant, participants for each item there were 5 people. Before conducting the test, each participant was given the opportunity to try it first and show the chest number to the officer so that the officer could easily record the test results. TKJI was held 2 times, namely the pretest and posttest. The steps to collect data were: (1) collecting samples (2) explaining the procedures and procedures for the Indonesian Physical Fitness Test (3) then the sample is asked to warm up (4) the sample is ordered to carry out the Indonesian Physical Fitness Test (5) recording the test results.

To obtain the data in this study used instruments in the form of Indonesian Physical Fitness Test (2010), physical fitness tests for children aged 10-12 years consisted of a series of five test items, namely (a) Sprint (dash / sprint) $40 \mathrm{~m}$, (b) Hang the elbow bend (c) lie down (sit-up 30 seconds), (d) Jump upright (vertical jump), and (e) Run away (600 meters).

Data analysis in this study used parametric statistics, by looking at the difference in average values between initial test values, namely tests using the Indonesian Physical Fitness Test before being treated with circuit training and final test values after being given circuit training. The significance of the statistical tests in this study was the t-test at the significance level of $5 \%$ or 0.05 . To analyze the t-test formula used for correlated samples.

\section{Discussion}

Description of research data served to facilitate the research data, description of research data included pre-test data and post-test data from the experiments conducted. In this discussion, one by one the research data was presented, from the pre-test and post-test data of the experimental group. The following description of the data obtained:

Table 1. Summary of Descriptive Analysis Results of Pre-Test and PostTest Physical Fitness

PJKR

http://jurnal.unimed.ac.id/2012/index.php/jpehr 
Makassar.

In The Fifth Grade Students of Rappocini Primary school in

\begin{tabular}{lll}
\hline Statistics value & Pre Test & Post Test \\
\hline$N$ & 30 & 30 \\
Mean & 15,70 & 20,17 \\
SD & 2,41 & 2,28 \\
Varians & 5,80 & 5,18 \\
Range & 9 & 10 \\
Minimum & 10 & 14 \\
Maximum & 19 & 24 \\
Sum & 471 & 605 \\
\hline
\end{tabular}

Test Requirements Analysis;

a. Data Normality Test

The normality test was conducted by using the Kolmogorov-Smirnov formula with the SPSS 21 program. The normality test results in the appendix can be seen in the table below:

Table 2. Summary of Data Normality Test Results

\begin{tabular}{cccc}
\hline Variable & KS-Z & Prob & Remark \\
\hline Pre Test & 0.819 & 0.513 & Normal \\
& & & \\
\hline Post Test & 0.857 & 0.455 & Normal \\
& & & \\
\hline
\end{tabular}

From the table above, it was known that the significant value of pre-test and post-test data was greater than 0.05 ( $\mathrm{Sig}>0.05$ ), then the hypothesis stated that the sample $_{\mid}$originates from fr normally distributed $_{\odot}$ population $_{+}$is $_{\mid}$accepted. Thus it was concluded that the normal distribution of pre-test and post-test data was fulfilled.

b. Data Homogeneity Test

Homogeneity test was conducted to find out the similarity of variance, or to test that the data obtained comes from a homogeneous population. Decision making criteria was accepted if the significant value was greater than 0.05 (Sig) 0.05). Homogeneity test results are as follows:

Table 3. Summary of Data Homogeneity Test Results

\begin{tabular}{cccc}
\hline $\begin{array}{c}\text { Levene } \\
\text { Statistics }\end{array}$ & Df1 & Df2 & Sig \\
\hline Pre Test & 6 & 21 & 0.135
\end{tabular}

Based on the table above, it was known that the significance value of physical fitness data in fifth grade students of Rappocini State Primary school Makassar showed a value of $0.715>0.05$, meaning that the data had the same

PJKR_ 
variant. Then it was said that the data came from homogeneous populations. So the hypothesis which stated that the data obtained from a homogeneous population was accepted.

1. Hypothesis Testing

Hypothesis testing in this study was "there is an effect of circuit training on physical fitness of the fifth grade students of Rappocini State Primary school in Makassar. To test the hypothesis of the data analysis was conducted by t-test on the pre-test data and post-test results the measurements of physical fitness level. In this test tested the hypothesis, there was a difference in the level of physical fitness. To accept or reject the hypothesis by comparing the price of $t$ arithmetic with the price of $t$ table, the criterion was to accept the hypothesis if the price of $t$ arithmetic lied between negative and positive from $t$ table, or if the significant calculation was greater than 0.05 .

To find out the difference in physical fitness level between physical fitness before being given the training circuit treatment with physical fitness and after being given the training circuit treatment used two-sample t-test or Paired samplet-test. T-test results are shown in the following table;

Table 4. Summary of T-Test Results

\begin{tabular}{llcll}
\hline Groups & Average & $\begin{array}{c}\mathrm{T} \\
\text { Count }\end{array}$ & $\begin{array}{l}\mathrm{T} \text { table } \\
\text { df }(\mathrm{N}-1) \\
=29\end{array}$ & Sig \\
\hline Pre Test & 15.70 & -26.107 & 2,045 & 0.000 \\
\hline Post Test & 20.17 & & & \\
\hline
\end{tabular}

The t-test results obtained $t$ value of -26.107 and the value of $t$ table in $\mathrm{dk}$ (19) of 2.045 with a significance level of 0.000 . Because the t value was greater than table $(-26,107>2,045)$ or was located outside the reception area of Ho, it was concluded that there was a significant difference in physical fitness of the fifth grade students of Rappocini State Primary school in Makassar between before and after the experiment.

Based on the table above, it could be seen that the average value for pretest data was 15.70 and the average value for post-test data was 20.17. These results indicated the level of physical fitness of fifth grade students at Rappocini State Primary school in Makassar after being treated with a circuit game training increased by $28.47 \%$. In this case, it could be said that the effect given by the circuit game training was $28.47 \%$.

This study aimed to determine the effect of the circuit training on improving physical fitness of primary school children, especially fifth grade students at SD Rappocini Makassar Pakem. The results showed that there were differences in physical fitness of the fifth grade students of Rappocini State Primary school in Makassar before and after the circuit training was conducted.

At the time of the pre-test, the average physical fitness was 15.70 , while at the post-test was 20.17. It turned out that after being treated by the circuit training,

PJKR

http://jurnal.unimed.ac.id/2012/index.php/jpehr 
the average of the physical fitness test results experienced a change of 4.47 , or $19.62 \%$. From the t-test analysis showed that there were significant differences, therefore this shows that the circuit training turned out to have a significant influence on improving physical fitness of fifth grade students in Rappocini State Primary school Makassar by $28.47 \%$.

Circuit training is a way to exercise physical conditions which aims and tries to develop cardiac, respiratory and blood vessel functions through the addition of repetitions with certain imposition and try to reduce the amount of time used to do a series of exercises. Physical fitness is a physical condition which has to do with the ability and power to function at work optimally and efficiently. The provision of circuit training to the fifth grade students of Rappocini State Primary school in Makassar was used to find out whether the exercise affected the physical fitness of their students or not. It turned out that after an experiment was carried out, and a study was conducted there appeared to be a significant increase in physical fitness of the fifth grade students of the Rappocini State Primary school in Makassar from the circuit training. Circuit training had an effect of $28.47 \%$. This goes back to the purpose of the training circuit which is to improve the work of the heart, respiatory and blood vessels. Because the work of the heart, respiratory and blood vessels can be optimal and efficient, one's physical fitness will increase.

\section{Conclusion}

Based on the results of data analysis, hypothesis testing and the discussion that stated in the previous chapter, so the conclusions in this study are as follows: There is an influence of circuit games on physical fitness in fifth grade students of Rappocini State Primary school in Makassar 2015/2016 Academic Year.

References
Harsono, 1988. Coaching dan Aspek-Aspek Psikologis dalam Coaching. Jakarta: Departemen Pendidikan dan Kebudayaan, Proyek Pengembangan Lembaga Pendidikan Tenaga Pendidikan.

Marsudi, 1997. Pendidikan Kesegaran Jasmani. Jakarta: Yudistira.

Sadoso Sumosardjuno, 1992. Pengetahuan Praktis Kesehatan dan Olahraga. Jakarta: Pustaka Kartini.

Santoso, dkk, 2007. Pendidikan Jasmani Olahraga dan kesehatan. Jakarta: Yudhistira

Sudarno, 1992. Pendidikan Kesegaran Jasmani. Jakarta: Departemen Pendidikan dan Kebudayaan.

Suharsimi Arikunto, 2002. Prosedur Penelitian. Jakarta. Penerbit Rineka Cipta. Sukrisno dkk, 2007. Penjas Orkes Untuk SD Kelas V. Jakarta: Erlangga. 